$\xi_{p}$

\title{
Diversity and Distribution of the Mangrove Gastropods of Kuala Selangor Nature Park, Selangor
}

\author{
A Jahid ${ }^{1,2}$, H R Singh ${ }^{1 *}$ \\ ${ }^{I}$ Department of Biology, Faculty of Applied Sciences, Universiti Teknologi MARA, 40450 Shah Alam Selangor \\ ${ }^{2}$ Department of Biology, Faculty of Education, Kandahar University, Afghanistan \\ *Corresponding author E-mail: harinderrai.singh@gmail.com
}

\begin{abstract}
This study reports on the diversity and distribution of mangrove gastropods from Kuala Selangor Nature Park sampled from August to November 2017. The line transect with quadrat method was employed to sample gastropods which were handpicked from the various mangrove structures (root, stem, branch) and mangrove floor within $5 \mathrm{~m}$ x $5 \mathrm{~m}$ quadrats. Nineteen gastropod taxa were recorded from the Bruguiera, mixed (Bruguiera, Avicennia \& Rhizophora), and Avicennia \& Rhizophora zones. The Ellobiidae (Elobium aurisjudae and Cassidula aurisfelis), Potamidae (Cerithedia obtusa, Cerithidea cingulata and Telescopium telescopium), Muricidae (Chicoreus capucinus) and Naticidae (Nerita balteata) were the most distributed gastropod families at the study site. Gastropod horizontal distribution varied between tree zones (Bruguiera; Bruguiera-Avicennia-Rhizophora; and Avicennia-Rhizophora) and tree type (Brugueira, Rhizophora and Avicennia), while gastropod vertical distribution varied based on height on tree $(0-120 \mathrm{~cm})$ and sub-habitats (roots, floor and trunk) as shown by the principle components analysis (PCA) biplots. The Margalef's species richness (D=2.90) and ShannonWeiner diversity $\left(\mathrm{H}^{\prime}=2.32\right)$ was low which is typical of mangroves that are mature while Pielou's evenness $(\mathrm{J}=0.77)$ was high implying lack of dominance by specific gastropod taxa.
\end{abstract}

Keywords: Mangrove; Gastropods; Diversity; Distribution; Kuala Selangor

\section{Introduction}

Mangroves are unique ecosystems of considerable significance found usually at the confluence of marine and terrestrial environments having global distribution within the tropical and subtropical regions [1] [2] [3]. The Indo-West Pacific has the largest mangrove area and diversity especially in South East Asia (SEA) [4]. Within SEA, Malaysia is second to Indonesia in size and diversity of its mangroves [1]. This distinctly productive environment houses an extensive variety of fauna such as gastropods, arthropods, fish, birds, reptiles, amphibians, mammals [1] and plants [5]. Besides habitats for fauna and flora, mangroves offer ecological services such as feeding, breeding and nursery grounds for commercially important finfish and shellfish [6], for wood products, pollution and sewage abatement, coastline protection, recreation and tourism [7].

Among the mangrove fauna, gastropods are an important component of the community. There is however paucity on their literature related to community structure and distribution especially at Kuala Selangor Nature Park notwithstanding past works on the taxa in other mangrove habitats in Malaysia [8] [9] [10] [11] [12] [13] [14] [15] [16].

This paper reports on the gastropod community of the mangroves of Kuala Selangor Nature Park. The park houses habitats such as mangroves, mudflats, a man-made lake and a secondary forest. Even though the park was established in 1987 [17], studies related to its mangrove ecology is scanty, especially those related to gastropods.

\section{Materials and methods}

\subsection{Study Site}

The study site is located at Kuala Selangor Nature Park, Kuala Selangor, Malaysia $\left(3.3390^{\circ} \mathrm{N}, 101.2448^{\circ} \mathrm{E}\right)$ (Fig.1). The park is noted for tourism, and education and awareness since its establishment. The main mangrove taxa that are found are Avicennia, Rhizophora and Bruguiera [17].

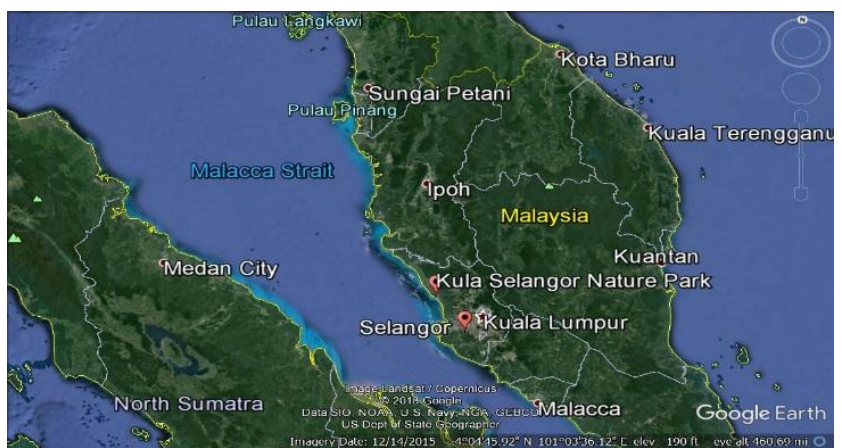

Figure 1: Location of Kuala Selangor Nature Park (source: Google Earth, 2018)

\subsection{Gastropod Sampling}

Gastropod sampling was conducted utilizing the line transect and quadrat method. The sampling area was subjected to representa- 
tive transect lines with quadrats of dimensions $5 \mathrm{~m}$ x $5 \mathrm{~m}$. The GPS coordinates of the transect lines are given in Table 1. Gastropods were collected by hand from the mangrove floor, roots and tree trunks. Sampled gastropods were put into labelled plastic bags and were brought back to the laboratory for identification, enumeration and measurement.

Table 1: Coordinates of Transect Lines at Kuala Selangor Nature Park

\begin{tabular}{|c|c|c|}
\hline \multicolumn{3}{|c|}{ Transect } \\
\hline Line & Starting point & Ending point \\
\hline \multirow{3}{*}{1} & $3^{\circ} 20^{\prime} 02.74^{\prime \prime} \mathrm{N}$ & $3^{\circ} 20^{\prime} 02.98 " \mathrm{~N}$ \\
\hline & $101^{\circ} 14^{\prime} 19.43^{\prime \prime} \mathrm{E}$ & $101^{\circ} 14^{\prime} 00.21^{\prime \prime E}$ \\
\hline & $3^{\circ} 20^{\prime} 05.08^{\prime \prime} \mathrm{N}$ & $3^{\circ} 20^{\prime} 06.05^{\prime \prime N}$ \\
\hline \multirow[t]{2}{*}{2} & $101^{\circ} 14^{\prime} 08.80^{\prime \prime} \mathrm{E}$ & $101^{\circ} 13^{\prime} 59.76^{\prime \prime} \mathrm{E}$ \\
\hline & $3^{\circ} 20^{\prime} 09.22 " \mathrm{~N}$ & $3^{\circ} 20^{\prime} 10.588^{\prime \prime N}$ \\
\hline \multirow[t]{2}{*}{3} & $101^{\circ} 14^{\prime} 09.96 " \mathrm{E}$ & $101^{\circ} 14^{\prime} 01.46^{\prime E} \mathrm{E}$ \\
\hline & $3^{\circ} 20^{\prime \prime} 12.89 " \mathrm{~N}$ & $3^{\circ} 20^{\prime \prime} 13.65^{\prime \prime} \mathrm{N}$ \\
\hline \multirow[t]{2}{*}{4} & $101^{\circ} 14^{\prime} 11.04 " \mathrm{E}$ & $101^{\circ} 14^{\prime} 04.45^{\prime \prime E}$ \\
\hline & $3^{\circ} 20^{\prime} 18.05^{\prime \prime} \mathrm{N}$ & $3^{\circ} 20^{\prime} 18.22 " \mathrm{~N}$ \\
\hline \multirow[t]{2}{*}{5} & $101^{\circ} 14^{\prime} 11.84^{\prime \prime} \mathrm{E}$ & $101^{\circ} 14^{\prime} 07.80^{\prime \prime} \mathrm{E}$ \\
\hline & $3^{\circ} 20^{\prime} 25.45^{\prime \prime} \mathrm{N}$ & $3^{\circ} 20^{\prime} 26.75^{\prime \prime} \mathrm{N}$ \\
\hline 6 & $101^{\circ} 14^{\prime} 13.89^{\prime \prime} \mathrm{E}$ & $101^{\circ} 14^{\prime} 08.24^{\prime \prime E}$ \\
\hline
\end{tabular}

\subsection{Identification}

Gastropods were identified utilizing taxonomic keys in [18] [19] [20] [21] [22] [23].

\subsection{Gastropod Community Analysis}

The following indices were utilized to compute gastropod species diversity: Margalef's species richness [42], D = (s-1)/log $\log _{e}$, Shannon-Weiner diversity index [43], H' $=-\Sigma \mathrm{p}_{\mathrm{i}} \log _{\mathrm{e}} \mathrm{p}_{\mathrm{i}}$; Maximum diversity, H'max $=\log _{\mathrm{e}} \mathrm{S}$; and Pielou's equitability or evenness, $\mathrm{J}=$ H'/H'max [44]

\subsection{Gastropod Distribution}

Gastropod horizontal zones was based on mangrove tree abundance: Bruguiera sp. zone (0-50m), mixed species zone (Brugueira sp., Rhizophora sp. and Avicennia sp.) (50-150m) and Rhizophora sp. and Avicennia sp. zone (150-200m). The horizontal distribution also expressed as quadrat distances from the coastal bund.

Gastropod vertical distribution was expressed as percentage number of gastropod species recorded from the roots, stem and branches of mangrove trees (sub-habitats) and as percentage number of gastropods along $10 \mathrm{~cm}$ interval scales from the mangrove floor.

\subsection{Statistical analysis}

Principal Components Analysis (PCA) [24] was utilized to show the ordination of the correlation of gastropod taxa to their horizontal (mangrove tree zones and the quadrat distance from coastal bund to mudflat edge) and vertical (height and sub-habitats) distributions. XLSTAT [25] was utilised to run the PCA.

\section{Result and discussion}

\subsection{Mangrove Tree Taxa}

Among the mangroves, Avicennia sp., Bruguiera sp. and Rhizophora sp. were recorded within the sampling quadrats at Kuala Selangor Nature Park (Table.2). Avicennia sp. recorded the largest Girth at Breast Height $(\mathrm{GBH})($ mean $=37.3 \pm 18.2 \mathrm{~cm})$ while Bruguiera sp. recorded the smallest $\mathrm{GBH}$ (mean=22.36 $\pm 8 \mathrm{~cm}$ ). Avicennia sp. and Rhizophora sp. abundance increased from the bund towards the mudflat edge $(50 \mathrm{~m}-200 \mathrm{~m}$ from the bund). Bruguiera sp. abundance decreased from the landward side to- wards the mudflat edge but its abundance was highest from the bund until 50m (Table. 2). Avicennia sp., Bruguiera sp. and Rhizophora sp. were also previously recorded from the mangroves at Kuala Selangor Nature Park [26].

Table 2: Mangrove Tree Distribution in Sampling Quadrats from Kuala Selangor Nature Park

\begin{tabular}{ccccc}
\hline $\begin{array}{c}\text { Mangrove } \\
\text { Taxa }\end{array}$ & $\begin{array}{c}\text { Bruguiera } \\
\text { zone }\end{array}$ & $\begin{array}{c}\text { Mixed } \\
\text { zone }\end{array}$ & $\begin{array}{c}\text { Avicennia \& } \\
\text { Rhizophora zone }\end{array}$ & $\begin{array}{c}\text { Mean } \\
\text { GBH }(\mathrm{cm})\end{array}$ \\
\hline & $(0-50 \mathrm{~m})$ & $\begin{array}{c}(50- \\
150 \mathrm{~m})\end{array}$ & $(150-200 \mathrm{~m})$ & \\
\cline { 2 - 4 } & $(\mathrm{no} / \mathrm{ha})$ & $(\mathrm{no} / \mathrm{ha})$ & $(\mathrm{no} / \mathrm{ha})$ & $37.3 \pm 18.2$ \\
$\begin{array}{c}\text { Avicennia } \\
\text { sp. }\end{array}$ & 333.3 & 810.1 & 3333.3 & $22.36 \pm 8$ \\
$\begin{array}{c}\text { Bruguiera } \\
\text { sp. }\end{array}$ & 4166.6 & 2546.2 & 1166.6 & $35.12 \pm 13$ \\
$\begin{array}{c}\text { Rhizophor } \\
\text { a } \text { sp. }\end{array}$ & 250 & 1273.4 & 4000 & \\
\hline
\end{tabular}

\subsection{Gastropod diversity}

Nineteen gastropod taxa were sampled from the mangroves of KSNP (Table 3). The Ellobiidae (Ellobium aurisjudae and Cassidula aurisfelis), Potamidae (Cerithidea obtusa, Cerithidea cingulata and Telescopium telescopium), Muricidae (Chichoreus capucinus) and Naticidae (Nerita balteata) were the most distributed gastropod families at the study site (Table 3). The Margalef index was 2.90, Shannon index, H' was 2.32 and the Pielou evenness, J, was 0.77 (Table. 4). The Margalef index (2.9) at KSNP is low when compared to other mangrove sites (Table 4), considering the index not having a limit. The index is somewhat useful for baseline comparison of habitats [27]. The Shannon index (2.32) is higher when compared to other mangrove sites, but is low as the value is smaller than 3.0 noting that the index can go higher than 4 [28]. The Pielou index (0.77) indicates that the gastropod taxa at KSNP are somewhat evenly numbered within sampling quadrats as its value is closer to 1 [28] implying lack of dominance by a few species and its value is higher than other mangrove sites (Table 5). The diversity indices recorded larger values from the mixed and the Avicennia \& Rhizophora zones, but higher at the latter (Table 4). The high mangrove molluscan diversity is generally attributed to microhabitat diversity and higher food availability [29].

\subsection{Gastropod Distribution}

\subsubsection{Gastropod horizontal distribution}

The PCA biplots show that Chicoreus copuchins, Littoraria conica, Littoraria scabra, Littoraria undulata, Littoraria malanostoma, Nerita violacea, Nerita cornocopria and Telescopium mauritsi correlate to the Avicennia-Rhizophora zone (150-200 m) (Fig. 2). Cassidula. aurisfelis, C. nucleus C. obtusa , N. balteata and S. miniata, correlate to the mixed zone (Bruguiera-AvicenniaRhizophora) (50-150 m) while C. cingulata, E. aurisjudae, P. plicata and $\mathrm{T}$. telescopium correlate to the Bruguiera zone $(0-50 \mathrm{~m})$ (Fig. 2).

With respect to tree type preference, the PCA biplots show that Cassidula nucleus, L melanostoma, L. undulata and Phythia plicata correlate mainly to Avicennia trees; $N$. balteata correlate to Rhizophora trees; and C. obtusa, C. copucius and E. aurisjudae correlate to Bruguiera trees. C. aurisfelis, L. conica and $L$. undulata on the other hand correlate to both Avicennia and Rhizophora trees (Fig. 3).

Table 3: Gastropods Taxa Distribution by Mangrove Zones at Kuala Selangor Nature Park

\begin{tabular}{|c|c|c|c|}
\hline \multirow[t]{2}{*}{ Gastropod Taxa } & $\begin{array}{l}\text { Bruguiera } \\
\text { zone }\end{array}$ & $\begin{array}{l}\text { Mixed } \\
\text { zone }\end{array}$ & $\begin{array}{l}\text { Avicennia \& } \\
\text { Rhizophora zone }\end{array}$ \\
\hline & $0-50(\mathrm{~m})$ & $\begin{array}{l}50-150 \\
(\mathrm{~m})\end{array}$ & $150-200(\mathrm{~m})$ \\
\hline
\end{tabular}




\begin{tabular}{|c|c|c|c|}
\hline $\begin{array}{l}\text { Cassidula } \\
\text { aurisfelis }\end{array}$ & + & + & + \\
\hline Cassidula nucleus & - & + & + \\
\hline $\begin{array}{l}\text { Cerithidea } \\
\text { cingulata }\end{array}$ & + & + & - \\
\hline Cerithidea obtusa & + & + & + \\
\hline $\begin{array}{l}\text { Chichoreus } \\
\text { copucinus }\end{array}$ & + & + & + \\
\hline Ellobium arisjudae & + & + & + \\
\hline Littoraria conica & - & - & + \\
\hline Littoraria scabra & - & - & + \\
\hline Littoraria undulata & - & + & + \\
\hline Nerita balteata & + & + & + \\
\hline $\begin{array}{l}\text { Sphaerassiminea } \\
\text { miniata }\end{array}$ & - & + & + \\
\hline $\begin{array}{l}\text { Telescopium } \\
\text { mauritsi }\end{array}$ & - & + & + \\
\hline $\begin{array}{l}\text { Telescopium } \\
\text { telescopium }\end{array}$ & + & + & + \\
\hline $\begin{array}{l}\text { Neritina } \\
\text { cornocorpia }\end{array}$ & - & - & + \\
\hline Nerita violacea & - & - & + \\
\hline Haminoea sp & - & - & + \\
\hline $\begin{array}{l}\text { Littoraria } \\
\text { melanostoma }\end{array}$ & - & + & + \\
\hline $\begin{array}{l}\text { Phythia plicata } \\
\text { Indothais }\end{array}$ & + & - & - \\
\hline rufotinacta & - & - & + \\
\hline
\end{tabular}

Table 4: Gastropod Diversity Indices Based on Mangrove Sampling Zones at Kuala Selangor Nature Park

\begin{tabular}{lccc}
\hline $\begin{array}{l}\text { Diversity } \\
\text { Index }\end{array}$ & $\begin{array}{c}\text { Brugiuera } \\
\text { zone }\end{array}$ & $\begin{array}{c}\text { Mixed } \\
\text { zone }\end{array}$ & $\begin{array}{c}\text { Avicennia \& Rhizophora } \\
\text { zone }\end{array}$ \\
\hline & & $(50-150$ & \\
H, Diversity & $(0-50 \mathrm{~m})$ & $\mathrm{m})$ & $(150-200 \mathrm{~m})$ \\
\cline { 2 - 4 } D, Richness & 1.34 & 2.27 & 2.39 \\
E, Eveness & 0.91 & 2.49 & 2.6 \\
\hline
\end{tabular}

Table 5: Diversity indices from various mangrove locations along the Selangor coast, Malaysia (PKl-Pulau Klang; PTe-Pulau Tengah; Pke-Pulau Ketam; PCMZ-Pulau Che Mat Zin)

\begin{tabular}{lcccc}
\hline \multicolumn{1}{c}{ Location } & $\begin{array}{c}\text { Margalef' } \\
\text { S, D }\end{array}$ & $\begin{array}{c}\text { Shannon- } \\
\text { Weiner,H }\end{array}$ & $\begin{array}{c}\text { Pielou, } \\
\text { E }\end{array}$ & $\begin{array}{c}\text { Refer- } \\
\text { ence }\end{array}$ \\
\hline KSNP & 2.9 & 2.32 & 0.77 & $\begin{array}{c}\text { present } \\
\text { study } \\
\text { Sungai Merbok }\end{array}$ \\
$\begin{array}{l}\text { PKI,Pte, Pke, PCMZ } \\
\text { Pristine) }\end{array}$ & 4.75 & 1.23 & 0.55 & {$[8]$} \\
\hline
\end{tabular}

Gastropod distribution in the mangrove ecosystem is affected by a variety of factors such as light, tidal exposure, salinity and sub-

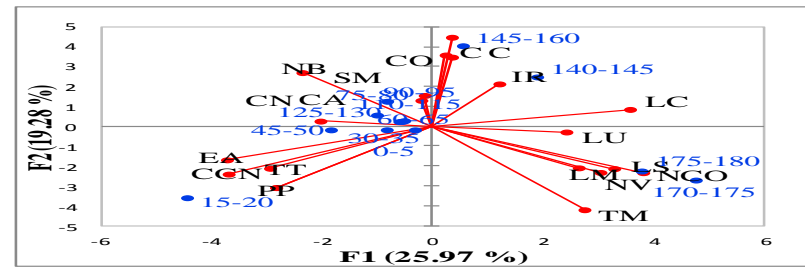

strate type [30]. The present study recorded wide distribution of Ellobiidae (E. aurisjudae, C. nucleus, and C. aurisfelis), Muricidae (C. capucinus), Naticidae (N. balteata) and Potamididae $(C$. obtusa, C. cingulata, T. telescopium). The Littorinidae, Potamididae, and Ellobiidae are known to be widely distributed in man Figure 2: PCA plot of gastropod taxa horizontal distribution [value range (m) represents quadrat distance from the coastal bund]. [CO (Cerithidea obtusa), CN (Cassidula nucleus), CA (Cassidula aurisfelis), NB (Nerithedia balteata), EA (Ellobium aurisjudae), IR (Indothais rufotinacta), LS (Littoraraia scabra), LC (Littoraria conica), LM (Littorara melanostoma), LU (Littoraria undulata), NCO (Nerita cornocorpia), NV (Nerita violacea), PP (Phythia plicata), TT (Telescopium telescopium), TM (Telescopium maurtsi), SM (Spharerassiminea miniata), CC (Chicoreus capocinus), CCN (Cerithidea cingulata) groves of the Indo-Pacific [31].

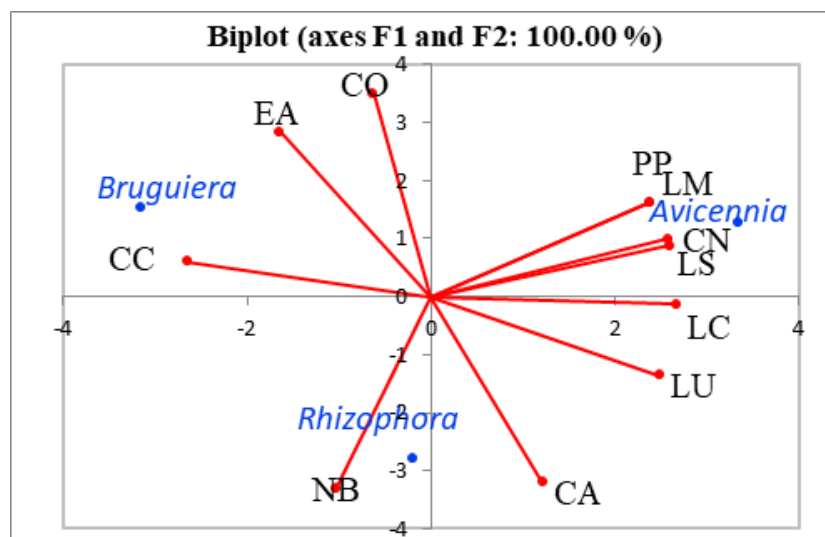

Figure 3: PCA plot of gastropod species distribution on mangrove trees.CO (Cerithidea obtusa), CC (Chicoreus copucinus), CN (Cassidula nucleus), CA (Cassidula aurisfelis), NB (Nerita balteata), PP (Phytia plicata), LS (Littoraria scabra), LM (Littoraria melanostoma), LC (Littoraria conica), LU (Littoraria undulata), EA (Ellobium aurisjudae)

Most gastropods were recorded from the Avicenna and Rhizophora zone which is closer to the mudflats. The structure of these trees (roots, pneumatophores and stems) create microhabitats resulting in diverse niches for the gastropods to fill [21]. Gastropod predation from Rhizophora trees is higher than on Avicennia trees [21] and this may have accounted for the larger number of gastropod taxa recorded from the Avicennia and Rhizophora zone which has more Avicennia trees as compared to the mixed zone. Lower taxa distribution at the Brugueira and the mixed zones may be related to lower food availability [32] and that mangrove sediments that are flushed less have higher salinity which may reduce food availability. Such conditions may prevail at the Bruguiera zone where the soil may have higher salinity due to lower flushing rates.

\subsubsection{Vertical Distribution of Gastropods}

Eleven gastropod taxa were recorded from the roots and stems of the mangrove trees. The PCA plot (Fig. 4) $(10 \mathrm{~cm}$ vertical intervals) shows that $C$. nucleus, $C$. aurisfelis, $C$. copucinusa, L. scabra, $L$. conica, L. melanostoma and $N$. balteata correlate to the $0-30 \mathrm{~cm}$ range; C. obtusa, E. aurisjudae, $L$. conica, $L$. undulata and $P$. plicata correlate to the $30-40 \mathrm{~cm}$ range

With respect to sub-habitats, the PCA plot shows that $C$. nucleus, C. aurisfelis, C. obtusa, C. cingulata, E. aurisjudae, Haminoea sp. I. rufotinacta, $N$. cornocorpia, S. miniata, T. telescopium and T. mauritsi correlate to mangrove floor; Littoria scabra, $L$. conica, $L$. melanostoma, L.undulata, N. violacea, P. plicata correlate to mangrove tree trunk while only $N$. balteata correlate to mangrove roots (Fig. 5).

Most gastropods sampled were mainly from the mangrove floor. Only 20\% of gastropods in mangroves are found on trees [33]. Almost all mangrove gastropods are categorized as tree climbers, moving up and down to follow the tide (vertical migration) but some move to the ground during low tide [34]. Tree-climbing behaviour is an adaptation to avoid predation by subtidal crabs and fish that forage at high tide [40] [39]) and also avoidance of physiological stress [41].

The mangrove gastropod vertical distribution indicates zonation patterns where they occupy a variety of microhabitats. While some species live on the mud surface, others live on tree trunks, roots and canopy [35] and the vertical distribution patterns among the gastropods may be related to diet preference as well as predator avoidance [9]. Gastropods are herbivores feeding on small algae distributed at different tide levels [36]. The littorinids, $L$. scabra, $L$. conica, L. melanostoma and L. undulata were recorded only from 
the mangrove trees in the present study. Littoraria sp. do not inhabit the mangrove floor because they feed on epibenthic films on stems and roots, and graze on the leaves for food. Littoraria scabra is an active gastropod and has the capacity to adjust within the intertidal zone such as adapting to dessication and has better predator avoidance compared to other littorinids [37]. The Littorinidae show diverse vertical locations in response to the alterations in the tide levels [38]. The Potamididae, for example, $C$. cingulata and C. obtusa, can inhabit both the mangrove floor during low tide, seeking trees and roots during high tide above the water line while $T$. telescopium and $T$. mauritsi only inhabit the mangrove floor [39]. The latter's preference for the mangrove

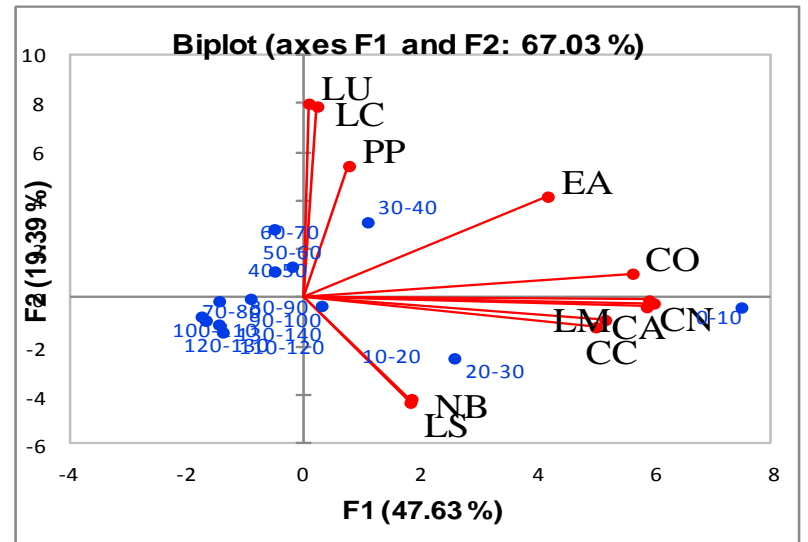

floor could be related to its preference for moist conditions and diet specificity.

Figure 4: PCA plot of gastropod species vertical distribution (Values shown are height range of $10 \mathrm{~cm}$ interval. CO (Cerithidea obtusa), CN (Cassidula nucleus), CA (Cassidula aurisfelis), CCO (Chicoreus capucinus), EA (Ellobium aurisjudae), LM (Littoraria melanastoma), LS (Littoraria scabra), LC (Littoraria conica), LU (Littoraria undulata), PP (Phythia plicata), NB (Nerita balteata)]

Climbing mollusks move downwards to lower zones as lunartidal-cycle change to neap tides, and crawl upwards as this cycle

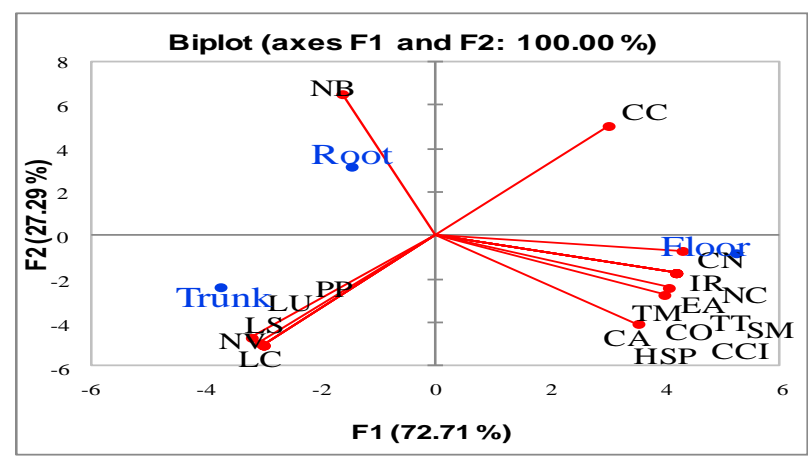

change to the spring tides as well as to daily floods and ebbs. Vertical alterations in substratum moisture, wave energy, salinity and food distribution differ with each lunar-tidal cycle that may disturb the vertical zonation of mangrove mollusks [30]. Vulnerability to predation as well as to microclimatic limits sets the lower and upper limits of vertical distribution of gastropods [39] while horizontal distribution however, is indicative of physiological tolerance [37].

Figure 5: PCA plot of gastropod species distribution based on sub habitats (Floor, Root \& Trunk) [CO (Cerithidea obtusa), CC (Chicorues copucinus), CCIN (Cerithidea cingulata), EA (Ellobium aurisjudae), IR (Indothais rufotinacta), LS (Littoraria scabra), LM (Littoraria melanostoma), LU (Littoraria undulata), SM (Sphaerassiminea miniata), HSP (Haminoea sp.) NCO (Nerita cornocorpia), NV (Nerita violacea) NB (Nerita balteat), CN (Cassidul nucleus), NC (Neritina cornocorpia), TT (Telescopium telescopium), TM (Telescopium mauritsi), CA (Cassidula aurisfelis)]

\section{Conclusion}

The Potamidae, Ellobiidae and Naticidae were the widely distributed taxa. Gastropod horizontal distribution was related to tree zonation patterns and species preference for tree type. Gastropod vertical distribution on tree trunk was related to height from the floor and species preference for sub-habitats (root, floor and tree trunk). The Margalef's species richness and Shannon-Weiner diversity was low probably indicating matured mangroves while Pielou's evenness was high implying low dominance by gastropod taxa.

\section{Acknowledgement}

The authors would like to thank the staff of Kuala Selangor Nature Park for assistance rendered and facilities during sampling. Thanks also to Universiti Teknologi MARA (UiTM) for use of space and equipment. This work would not have been completed without the help of Wan Mohammad Nabil in field sampling and Norashekin Kamal Baharin in species identification.

\section{References}

[1] FAO (2007) The World's Mangroves 1980-2005, FAO Forestry Paper 153. Rome: Forest Resources Division, FAO. 77 pp.

[2] Alongi, D. M, (2002). Present state and future of the world's mangrove forests, Journal of Environmental conservation, 29(03), 331 349, available online: https://www.cambridge.org, last visit: 1.07.2018.

[3] Tomlinson P B. (1986). The botany of mangroves. Cambridge: Cambridge University Press.25pp.

[4] Sandilyan, S., \& Kathiresan, K. (2012). Mangrove conservation: a global perspective. Biodiversity and Conservation, 21(14), 35233542.111, available online: https://link.springer.com, last visit: 127.07.2018.

[5] Ong, O. J. (1993). Mangroves-a carbon source and sink. Chemosphere, 27(6), 1097-1107, available online: https://www.sciencedirect.com, last visit: 15.07.2018.

[6] Ashton, E.C. Macintosh, D.J. \& Havanon, S. (2002). Mangrove Rehabilitation and Intertidal Biodiversity: a Study in the Ranong Mangrove Ecosystem, Thailand. Estuarine. Coastal and Shelf Science 55: 331-345. available online: http://www.idealibrary.com, last visit: 15.07 .2018

[7] Spalding, M., Kainuma, M., \& Collins, L. (2010). World atlas of mangroves. A collaborative project of ITTO, ISME, FAO, UNEPWCMC'. London, UK: Earthscan.120pp.

[8] Hookham, B., Shau-Hwai, A. T., Dayrat, B., \& Hintz, W. (2014). A Baseline Measure of Tree and Gastropod Biodiversity in Replanted and Natural Mangrove Stands in Malaysia: Langkawi Island and Sungai Merbok. Tropical life sciences research, 25(1), 1 Hydrobiologia 430:185-205.Indo-West Pacific region. Tropical Life Science Research. 6: 73-230, available online: https://www.ncbi.nlm.nih.gov, last visit: 20.7.2018.

[9] Berry, A. J. (1972). The natural history of the West Malaysian mangrove faunas. Malayan Nature Journal, 25:135-162 Biologia Tropical 50:1101-1112, available online: https://ci.nii.ac.jp/naid, last visit: 4.07.2018

[10] Sasekumar, A. (1974). Distribution of Macrofauna on a Malayan Mangrove Shore. Journal of Animal Ecology, 43(1), 51-69. doi:10.2307/315, available online: https://www.jstor.org, last visit: 15.07.2018.

[11] Schilthuizen, M., Vermeulen, J. J., \& Lakim, M. (2011). The land and the man-grove snail fauna of the islands of Banggi and Balambangan (Mollusca: Gastropoda). Journal of Tropical Biol-ogy \& Conservation (JTBC), available online: https://scholar.google.com, last visit: 15.07.2018.

[12] Ashton, E.C., Macintosh, D.J. \& Hogarth, P.J. (2003). A baseline study of the diversity and community ecology of crab and molluscan macrofauna in the Sematan mangrove forest, Sara-wak, Malaysia. Journal of Tropical Ecology 19:127-142, available online: https://www.cambridge.org, last visit: 4.07.2018.

[13] Faezah, P. \& Farah, H.S. (2011). Composition of gastropods in mangroves of Tanjung Dawai and Pulau Sayak, Kedah. Malays 
Journal of Malaysian Applied Biology. Biol. 40 (1): 13-17, available online: http://journalartcle.ukm.my, last visit: 15.07.2018.

[14] Cob, Z. C., Samat, A., Muda, W. M. L. W., \& Mazlan, A. G. (2012) Preliminary checklist of marine invertebrate fauna within the intertidal of Teluk Penyabong and Teluk Gorek, Mersing, Johor, Malaysia. Journal of Tropical Marine Ecosystem, 2(1), available online: http://spaj.ukm.my, last visit: 15.07.2018.

[15] Singh, H.R. (2013). Mangroves and Gastropods. Marine Biodiversity Expedition Report 2012: Central and Southern Straits of Malacca - Sembilan Islands, Tanjung Tuan \& Merambong Shoal. Vol.2. Department of Marine Park Malaysia, Putrajaya. pp. 15 - 30

[16] Singh, H. R., \& Norashekin, K.B. (2016). Gastropod community structure from varying levels of mangrove disturbance in Selangor, Malaysia. Malaysian Forester, 79(1-2), 54-63, available online: http://malaysianforester.my, last visit: 18.07.2018.

[17] Asmawi, M. Z., \& Paiman, T. (2015). Natural heritage of environmentally sensitive areas in Kuala Selangor district, Malaysia. Journal of International Proceedings of Chemical, Biological and Environmental Engineering (IPCBEE), 91, 38-42, available online: http://irep.iium.edu.my, last visit: 4.07.2018.

[18] Arnold, P.W. 1989. Mollusca. In: Arnold, P.W. \& Birtles, R.A. (Eds.). Soft- sediment marine invertebrates of Southeast Asia and Australia: a guide to identification. Townsville: Australian Institute of Marine Scince. 272pp.

[19] Chuang S.H. 1961. On Malayan Shores. Muwu Shosa, Singapore. $225 \mathrm{pp}$.

[20] Carpenter, K.E. \& Niem, V.H. (Eds.). (1998). FAO species identification guide for fishery purposes: The living marine resources of the Western Central Pacific, Volume 1: Seaweeds, corals, bivalves and gastropods. Rome: FAO. 686pp.

[21] Reid, D. G. 1986. The littorinid molluses of mangrov forsts in the Indo-Pacific region. Great Britain: British Museum (Natural History). $227 \mathrm{pp}$.

[22] Tan, S.K., Chan S.Y. \& Clements, G.R. 2012. A guide to snails and other nonmarine molluscs of Singapore. Singapore: Singapore Science Centre. $176 \mathrm{pp}$.

[23] Van Benthem-Jutting, W.S.S. (1948). Systematic studies on the non-marine mollusca of the Indo-Australian Archipelago: Journal of Indo-Australian Archipelago: 5 parts (Volumes 19-23). Amsterdam: Zoological Museum, available online: http://dx.doi.org, last visit: 20.7 .2018 .

[24] Janžekovič, F., \& Novak, T. (2012). PCA-a powerful method for analyze ecological niches. In Principal component analysismultidisciplinary applications. InTech, available online: https://www.intechopen.com, Last visit: 20.7.2018.

[25] XLSTAT. (2017). Data Analysis and Statistical Solution for Microsoft Excel. Addinsoft, Paris,France(2017), available online: https://help.xlstat.com, last visit: 20.7.18.

[26] Asmawi, M. Zainora, Abdul Aziz, Zainul Ariffin, and Hassan Abdulaziz. "Wetland management of Kuala Selangor Nature Park, Malaysia." In Proceedings of JSPS-VCC Core University Program International Seminar on Wetlands and Sustainability 2009, pp. $77-$ 98. KAED, IIUM, 2009, available online: http://irep.iium.edu.my/3336/, last visit: 14.8.2018

[27] Hazarika, L. P. (2013). Diversity indices of macro invertebrates in the Satajan Wetland of Lakhimpur District, Assam. Journal Annals of Biological Research, 4(8), 68-72, available online: https://scholar.google.com, last visit 20.7.2018.

[28] Mandaville, S. M. (2002). Benthic macroinvertebrates in freshwaters: Taxa tolerance values, metrics, and protocols Nova Scotia: Soil \& Water Conservation Society of Metro Halifax. (pp. 21-38).

[29] Fratini, S., Vigiani, V., Vannini, M., \& Cannicci, S. (2004). Terebralia palustris (Gastropoda; Potamididae) in a Kenyan mangal: size structure, distribution and impact on the consumption of leaf litter. Marine Biology, 144(6), 1173-1182, available online: https://link.springer.com, last visit: 21.7. 2018.

[30] Nagelkerken, I. S. J. M., Blaber, S. J. M., Bouillon, S., Green, P., Haywood, M., Kirton, L. G., ... \& Somerfield, P. J. (2008). The habitat function of mangroves for terrestrial and marine fauna: a review. Aquatic botany, 89(2), 155-185, available online: https://www.sciencedirect.com, last visit: 23.8.2018.

[31] Reid, D. G. (2014). The genus Cerithidea Swainson, 1840 (Gastropoda: Potamididae) in the Indo-West Pacific region. Zootaxa, 3775(1), 1-65, available online: https://www.biotaxa.org, last visit 13.8.2018.
[32] Kristensen, I. (1965). Habitat of the tidal gastropod. Echininus nodulosus. Basteria, 29(1/4), 23-25, available online: http://natuurtijdschriften.nl, last visit: 21.7.2018.

[33] Cantera J., Arnaud P. M., Thomassin B. A. (1983). Biogeographic and ecological remarks on molluscan distribution in mangrove biotopes. 1. Gastropods. Journal of Molluscan Studies 12A:10-26, available online: https://academic.oup.com, last visit: 20.7.2018.

[34] Tee, A. C. G., 1982b. Some aspects of the ecology of mangrove forests at Sungei Buloh, Selangor. II. Distribution pattern and population dynamics of tree-dwelling fauna. Malayan Nature Journal, 35: 267-277, available online: http://agris.fao.org, last visit: 11.8.2018

[35] Ashton, E.C. (1999). Biodiversity and community ecology of mangrove plants, molluscs andcrustaceans in two mangrove forests in Peninsular Malaysia in relation to managementpractices. Ph.D. Thesis. University of York, UK.87pp.

[36] Mohd Nasaruddin, H. (2006). Benthic microalgaea ssemblage osf Asajaya mangrove area, Kora Samarahan, Sarawak. Project report, Department of Aquatic Science, Faculty of Resource Science and Technology, Universiti Malaysia Sarawak, $67 \mathrm{pp}$.

[37] Alfaro, A.C. (2007). Migration and trail affinity of snails, Littoraria scabra on mangrove trees of Nananu-i-ra, Fiji Islands, Journal of Marine and Freshwater Behaviour and Physiology, vol. 40, pp. $247-$ 255, available online: https://www.tandfonline.com, last visit: 6.08.2018

[38] Blanco, J. F., \& Cantera, J. R. (1999). The vertical distribution of mangrove gastropods and environmental factors relative to tide level at Buenaventura Bay, Pacific coast of Colombia. Bulletin of marine science, 65(3), 617-630, available online: https://www.ingentaconnect.com, last visit: 11.8.2018.

[39] Vannini, M., Rorandelli, R., Lähteenoja, O., Mrabu, E., \& Fratini, S. (2006). Tree-climbing behaviour of Cerithidea decollata, a western Indian Ocean mangrove gastropod (Mollusca: Potamididae). Journal of the Marine Biological Association of the United Kingdom, 86(6), 1429-1436, available online: https://www.cambridge.org, last visit: 20.7 .2018

[40] Reid, D.G. (1992). Predation by crabs on Littoraria species (Littorinidae) in a Queensland mangrove forest. Mill, P.J. \& Reid, D.G. (Eds.) Proceedings of the Third International Symposium on Littorinid Biology. Malacological Society of London, pp. 141-151

[41] McGuiness, K.A. (1994). The climbing behaviour of Cerithidea anticipate (Mollusca: Gastropoda): the role of physical and biological factors. Australian Journal of Ecology, 19 (3), 283-289

[42] Margalef, R. (1968). Perspectives in ecological theory.55p.

[43] Shannon, C. E., \& Weaver, W. (1963). The mathematical theory of communication. $1949.112 \mathrm{p}$.

[44] Pielou E.C., 1975. - Ecological diversity. Wiley, New York, 165 p. 